Authors: D Smit and V du Plessis

SEXUAL HARASSMENT IN THE EDUCATION SECTOR

ISSN 1727-3781

2011 VOLUME 14 No 6

http://dx.doi.org/10.4314/peli.v14i6.6 


\title{
SEXUAL HARASSMENT IN THE EDUCATION SECTOR
}

\author{
D Smit* \\ V du Plessis ${ }^{* *}$
}

\section{Introduction}

Sexual harassment in the education sector is a burning issue, both in South Africa and in foreign jurisdictions. However, because of the lack of reliable statistics, this issue has had to be managed in the dark in South Africa. The Commission for Conciliation, Mediation and Arbitration (CCMA) does not keep separate statistics for sexual harassment cases. Such statistics merely form part of the larger category of unfair dismissals. The history and sociology underlying sexual harassment have been disregarded to a great extent due to the emphasis that is being placed on avoiding liability. Sexual harassment in schools is a way of expressing and confirming masculinity within a heterosexualised racial and gender order.

Not only is an employer subject to strict liability if a case of sexual harassment occurs in the workplace or at learning institutions, but a plethora of claims can follow and has been known to follow the employer of the harasser. This applies especially to the education sector where the in loco parentis principle reigns supreme and where codes of conduct and policy need to be developed to protect both learners and educators. A study done in America shows that nearly two thirds of all college students experience sexual harassment during their tuition and that female learners are predominantly the victims. It has also been found that gendered performance intersects intimately with relations of power. The reinforcement of male heterosexuality and the authentication of male masculinity are often the cause of females becoming victims of the sexual harassment in an education environment.

Denine Smit, Lecturer in Mercantile Law, Faculty of law, University of the Free State. E-mail: SmitDM@ufs.ac.za.

** Voet du Plessis, Professor in Mercantile Law, Faculty of law, University of the Free State. E-mail: DPlessJV@ufs.ac.za. 
Tertiary institutions and schools are no longer the ivory towers of the past. They have become a breeding ground for unfair discrimination and victimisation on sexual grounds. Gender stereotyping is one of the main reasons for the high number of sexual harassment cases reported in the education sector in South Africa and other jurisdictions. Only if the socio-political, historical and cultural factors underlying this phenomenon are fully understood can sexual harassment ever be eliminated.

As part of the expanding global village, South Africa has a variety of cultures and races of which the education sector must take cognisance in order to fully eradicate all forms of sexual harassment in education.

\section{Background as to why sexual harassment manifests in the learning environment}

According to Robinson ${ }^{1}$, empirical evidence from studies done in Australia over a ten-year period shows that the relationship between masculinity and sexual harassment in secondary schooling still stems from the perception that men, collectively, have power over women and that the very definitions of manhood maintain this notion. Sexual harassment seems to be integral to the performance of homogenised masculinity. ${ }^{2}$ It is a powerful means to reinforce culturally dominant relations of gender across class, race, and sexual orientation. ${ }^{3}$

The connection between sexism and harassment cannot be stressed enough. Victims often ask themselves what they have done wrong, what part of the problem they own, what they have done to contribute to sexual harassment, what they have wrongly observed and to what they have silently given consent. ${ }^{4}$ Sexual harassment often occurs where in the eyes of male colleagues the woman's sex role overshadows her role as an employee. ${ }^{5}$ It is against this backdrop of women's history that sexual harassment has been silenced for years and continues to pose a

\footnotetext{
Robinson 2000 Studies in Cultural Politics of Education 19-37.

Robinson 2000 Studies in Cultural Politics of Education 19-37.

Robinson 2000 Studies in Cultural Politics of Education 23.

Dziech and Weiner Lecherous Professor xxvi.

Ristow Sexual Harassment 4.
} 
problem. It must be kept in mind that learning institutions are not only vehicles for teaching learners but remain a workplace for educators as well.

\section{The problem of sexual harassment in the education sector}

\subsection{General}

Whereas sexual harassment often begins in elementary school it often escalates in high school, both in frequency and type, as students progress through school to tertiary institutions. This phenomenon has been described as a "disturbingly prevalent trend."6

Sexual harassment at universities has been understood as the exercise of power by specific individuals, and it has been dealt with via insufficient policies and grievance procedures. From an article written by Linda Eyre from the University of Brunswick, it is clear that this problem is far greater than the mere deviance by individual students. ${ }^{7}$ It is alleged that women's voices are silenced in university communities by those that hold powerful positions and that due to confidentiality clauses this serious problem has not received the attention it should. Catharine MacKinnon first brought the problem of sexual harassment on campus to the attention of the broader community. She described the harassment of students, especially female students, as a form of violence against women and coined the term "sexual harassment." The book "The Lecherous Professor" 8 refers to a survey of the Fortune 500 companies in which it was found that 90 percent of the top 500 companies had received sexual harassment complaints, more than 30 percent had been sued, and 25 percent had been sued more than once. The same problem was experienced by all - the lack of a mechanism that would encourage victims to come forward and use the system. It is argued that the number of formal and informal complaints remains minuscule in comparison with the total number of incidents of sexual harassment, either in the workplace or in schools or universities. ${ }^{9}$

6 Cherner-Ranft 2003 NW U L Rev 1891-1892.

7 Eyre 2000 Gender and Education 293.

8 Dziech and Weiner Lecherous Professor xiv.

9 Dziech and Weiner Lecherous Professor xiv. 
It is further stated that sexual harassment by university professors of their female students is a fact of campus life and that the silencing thereof is part of the reason for the historical invisibility of the problem: silence, promoted by the fear that somehow they (the victims) are responsible for the sexual harassment in one way or the other, and/or the fact that students know they are subordinate to faculty staff and administrators. ${ }^{10}$

The most prevalent defence is that it is the students who harass the professors. However, according to the writer of this book, students are capable of sexual hassle but not sexual harassment due to the absence of power on the side of the student. The fact that sexual hassle is in existence is not a reason for tolerating or ignoring sexual harassment. ${ }^{11}$ The fact that mutual consent is often raised as a defence by male professors can also not stand the test of time. Sexual give-and-take is based upon mutual consent, which is not possible in the student-teacher relationship because of the power imbalance and the magnitude of the role disparity. It must be kept in mind that in sexual harassment the concern is about the unhealthy sexual dynamic, about behaviours that are exploitative, abusive and psychologically and academically damaging. ${ }^{12}$ It has been the primary task of academia to educate and to pursue knowledge, but now the faculty are also tasked to clarify values, to develop character, to impart wisdom, to nurture good citizenship, to foster creativity and to encourage growth ${ }^{13}$. In this new plight the role of professors has changed, allowing for closer contact with students to facilitate the required "relate to student" dichotomy. This autonomy offers sanctuary to professors and may cause hazard to students. ${ }^{14}$

Different people have different forms of power over subordinates in commercial and non-commercial organisations and are able to abuse that power within those limits. The supervisor has power over the subordinate as the teacher has over his learners and as professors have over their students. "According to researchers who study sexual harassment in secondary schools, this organisational power perspective can

10 Dziech and Weiner Lecherous Professor 16.

11 Dziech and Weiner Lecherous Professor 25.

12 Dziech and Weiner Lecherous Professor 25.

13 Dziech and Weiner Lecherous Professor 41.

14 Dziech and Weiner Lecherous Professor 44. 
explain the sexual harassment of pupils by teachers." ${ }^{15}$ It is this potential abuse of power that links sexual harassment in education to the workplace.

\subsection{The "silent" problem in education - male learners harassing female educators}

This form of harassment of females in schools, especially secondary schools, has not received the attention it should and poses a real problem in several jurisdictions. This type of harassment seems to reverse the usual pattern. It leads not only to women having to defend their claims of sexual harassment but also challenges women to question the phenomenon of sexual harassment in the traditional sense. It has been pointed out that abuse has traditionally been effected by men in power positions and that sexual harassment implies the misuse of their position of trust. ${ }^{16}$ None of these traits is displayed when male learners sexually harass their female educators. The previous explanation of the social power differentiations between masculinity and femininity cannot come into play in this instance. This differentiation permeates the learner/educator domain. It becomes evident when male students undermine classroom management in the traditional Western discourse of authority by relying on the construction that children are perceived as "innocent" and "naïve" in relation to "adult" concepts such as sexuality, gender and power ${ }^{17}$, which proves not to be the case. Australia's Sex Discrimination $A c t^{18}$, which underwent significant changes in 1992, acknowledges that students could sexually harass their teachers and provides for legal recourse if the perpetrating learner is 16 years of age or older. This provision does not exist in South African law and surely is a lacuna.

The so-called "gender regime" presents itself in schools and refers to the traditional perceptions of authority as being male dominant. Historically women in education were seen to be poor disciplinarians, lacking male attributes to control especially older children and more specifically boys. Authority and discipline were predominantly defined in hegemonic masculine terms and confirmed by the sexual division of labour where men created policy, saw to discipline and were the decision

15 Timmerman 2003 Sex Roles 232.

16 Robinson 2000 Studies in Cultural Politics of Education 75.

17 Robinson 2000 Studies in Cultural Politics of Education 75.

18 Sex Discrimination Act 1986 (Chapter 59 UK). 
makers. ${ }^{19}$ As if that was not enough, according to an article written by K. Robinson of the University of Australia, ${ }^{20}$ gendered authority was present in non-traditional female subjects such as physics, computing, chemistry and others, which traditionally reflected a strong masculine bias. This presents a problem in modern society. The study showed that boys would challenge not only the authority of their female teachers but also question female educators' authority over and knowledge of their subjects. They would ask male teachers to assist them in these traditionally male environments, even outside the classroom. It is argued that in the Western world "masculinity comes to define valued experience" ${ }^{21}$ and those that do not fit the profile as being male, white, heterosexual and middle class are seen to be lacking authority. It is this perceived lack of authority that leads to female educators being harassed. The fact that male teachers often entered female classrooms unauthorised to manage what they perceived as a disciplinary problem occurring in the class further contributed to the undermining of female educators' authority in the eyes of learners. In the education sphere it is of the utmost importance that female educators be perceived to be able to maintain discipline as, according to this study, students believed that males were stronger, louder, had more control, were more intimidating than females and thus had greater authority. Students clearly associated power and authority with dominant male attributes and powerlessness with femininity. It is from this premise that female teachers were regarded as easy targets for practical jokes and were less respected by students. ${ }^{22}$ Since boys dislike being reprimanded by female teachers in class, constant battles ensue that are representative of a power battle in the small. The study showed that female teachers also believed that male teachers had an advantage over them as owing to their masculinity they possessed more disciplinary power. This masculinity is based purely upon the masculine body, as represented by the male's size and strong vocal cords. This is reminiscent of the subservient role women played in early history. It is a reminder that even in modern society, the notion of female subservience is confirmed and that the mere fact that women have entered the modern workplace is not enough to manage perceptions of female inferiority.

19 Robinson 2000 Studies in Cultural Politics of Education 78.

20 Robinson 2000 Studies in Cultural Politics of Education 75-80.

21 Robinson 2000 Studies in Cultural Politics of Education 78.

22 Robinson 2000 Studies in Cultural Politics of Education 79. 
In adolescence, specifically in male students, the link between daily practices and organisations of power lies in the differentiation between male and female bodies. This is where the problem starts. "For many adolescent males, their bodies can also become an effective resource to intimidate girls and women, especially in the context of sexual harassment." ${ }^{23}$ Daily contact between boys and female teachers often results in boys utilising sexual harassment to gain and shift power relations within the school and classroom, thereby transgressing the established and institutionalised power relations between teacher and student. It must be kept in mind that the teacher is the in loco parentis figure and should not be a pawn on a chessboard. In challenging female authority, boys do not display fear of repercussion. The very nature of committing sexual harassment in the open leads to its silencing in the hallways of schools. Boys use sexual harassment of female teachers as a means to undermine the feminine and confirm their masculinity. In this sense the gendered status quo is maintained in schools. One of the problems presented in this type of harassment is the fact that the victim often gets blamed for sexual harassment committed against her, the reason being given as her inability to maintain proper discipline. Teachers who have complained of sexual harassment have been branded as "poor teachers" by fellow teachers, students and executive members because "good teachers" are judged on how well they maintain discipline. Power issues, gender issues and other social forces all work together to set the scene for sexual harassment by learners of their female teachers. For as long as the sexual harassment of female teachers is seen to be a "discipline" problem the silence in this regard will continue. ${ }^{24}$ In this respect female teachers remain the victims of their own biology. To be victorious, they should be aware of this and address their own actions to bring into the open their sexual harassment experience, as it is unfair per se.

This study links up with cultural factors as well. It was found that boys from nonEnglish households were more prone to be perceived as harassers, especially those from southern Europe and Middle Eastern countries, who are perceived to be products of their machismo and misogynist cultures. However, this was found to be nothing more than a mere perception. It was also just a perception that boys of slow

23 Robinson 2000 Studies in Cultural Politics of Education 80.

24 Robinson 2000 Studies in Cultural Politics of Education 84. 
learning ability were more likely to harass due to their incapability to control their sexual urges. This proved to be a fallacy as well, as the study found that boys from Celtic backgrounds and those from non-Celtic backgrounds are equally likely to harass, irrespective of their intellectual ability. ${ }^{25}$

\subsection{Does sexual harassment present itself in the learning environment in South Africa?}

An investigation lodged into allegations of the serious and persistent sexual harassment of learners in South African schools led by the Human Rights Commission in 2001 has revealed that sexual harassment in South African schools is rife and poses a real threat to learners in particular. Equal learning opportunities cannot be guaranteed in such a negative environment. No official data could be found on the prevalence of sexual harassment in tertiary institutions. Data on harassment in schools are few and varied and are often the result of an independent study in a specific geographical area. Nevertheless, all the relevant material points to a problem of majestic importance and magnitude.

Sexual harassment in education should be regarded as extremely serious, especially in view of the special nature of the relationship between educators and learners. The in loco parentis principle should protect learners, not extradite them. This principle entails a two-tier approach. Firstly, educators are obliged to perform a duty of care as if the educator is the diligens paterfamilias at all times. This role is equal to the role of a father in his family. Educators are legally and ethically obliged to protect learners from sexual harassment and violence at school. The second tier of the in loco parentis principle is that educators are obliged to keep the peace and maintain order and discipline at schools. ${ }^{26}$ The mere fact that educators fill the in loco parentis role for learners renders any form of sexual involvement inappropriate. The authority that an educator holds over a learner creates the opportunity for abuse and the learner may feel disempowered to refuse the sexual attention of the educator. ${ }^{27}$ In this sense one cannot argue that any "consent" was real and

25 Robinson 2000 Studies in Cultural Politics of Education 86.

26 Prinsloo 2006 SAJE 312.

27 De Wet and Oosthuizen 2007 TG Supp 87. 
voluntarily afforded, as fear and undue influence play a huge role in the learner's reaction, coupled with the possibility of the misuse of power. Section 17 of the Employment of Educators Act $^{28}$ prohibits educators from committing sexual or any other form of harassment, which by implication prohibits them from having sexual relations with learners. If any educator is found to have transgressed this prohibition, such an educator is guilty of misconduct in terms of the Act and liable to suspension.

The Criminal Law (Sexual Offences and Related Matters) Amendment Act ${ }^{29}$ sets the age requirements of consent for sexual acts. Sections 15(1) and 16(1), read with the definition of "child" in section 1, criminalises so-called consensual penetration or sexual violation ${ }^{30}$ of a child (male or female) between 12 and 16 . Section $57(1)$ provides that no person under the age of 12 is capable of consenting to any sexual act. The Act further criminalises any attempt, conspiracy, or incitement to commit a sexual offence. This Act also creates a duty to report sexual offences committed with or against children and creates a National Register for sex offenders. ${ }^{31}$ This aspect will be dealt with infra. Part 3 of the Act contains provisions stipulating that learners, even above the age of 18, are not to be exposed to, compelled or caused to witness certain sexual acts, including but not limited to so called "flashing", exposure to child pornography or engagement of sexual services of a person older than the majority age of 18 . It must be kept in mind that learners may have reached the majority age whilst they are still attending schools as legitimate learners. These

28 Employment of Educators Act 76 of 1998.

29 Criminal Law (Sexual Offences and Related Matters) Amendment Act 32 of 2007.

30 The definition in $s 1$ of the Act provides: " 'sexual violation' includes any act which causes (a) direct or indirect contact between the (i) genital organs or anus of one person or, in the case of a female, her breasts, and any part of the body of another person or an animal, or any object, including any object resembling or representing the genital organs or anus of a person or an animal; (ii) mouth of one person and (aa) the genital organs or anus of another person or, in the case of a female, her breasts; (bb) the mouth of another person; (cc) any other part of the body of another person, other than the genital organs or anus of that person or, in the case of a female, her breasts, which could (aa) be used in an act of sexual penetration; (bb) cause sexual arousal or stimulation; or (ccc) be sexually aroused or stimulated thereby; or (dd) any object resembling the genital organs or anus of a person, and in the case of a female, her breasts, or an animal; or (iii) mouth of the complainant and the genital organs or anus of an animal; (b) the masturbation of one person by another person; or (c) the insertion of any object resembling or representing the genital organs of a person or animal, into or beyond the mouth of another person, but does not include an act of sexual penetration, and 'sexually violates' has a corresponding meaning."

31 Section 111-128 Criminal Law (Sexual Offences and Related Matters) Amendment Act 32 of 2007. 
aspects should be highlighted in all Codes of Conduct as a firm reminder of criminal liability.

According to Prinsloo, literature in South Africa shows that more than 30 percent of girls are raped at school. With HIV/AIDS prevalence measured at 22.9 percent for young girls and boys, sexual harassment in education becomes even more serious. It has been found that many girls experience violence at school, are raped, sexually abused, sexually harassed and assaulted by male learners and educators. ${ }^{32}$ The Human Rights Watch in 2001 reported that they experienced emotional pressure and denial of their self-respect, coupled with pregnancy fears, as additional stress factors. ${ }^{33}$

The Sunday Times of 23 November 2003 reported that 32 educators had been dismissed from 2000 to 2003, mainly for having had sex with learners. The South African Council for Educators (SACE) does not condone such behaviour even if there were consent. It points out that in the power imbalance situation where the educator has all the power, the educator is exploiting his position of trust. On instruction of Kader Asmal, Minister of Education at the time, the SACE even set up a 24-hour hotline to manage this problem in schools.

The Mail and Guardian of 30 January 2004 and 5 February 2004 reported that 24 percent of victims were between the ages of seven and fourteen. A study carried out by the Women's Legal Centre indicated that more than 30 percent of all girls who had been raped were raped at school. ${ }^{34}$

Girls have equal access to schools and achieve at an equal level at school ${ }^{35}$ but the question arises if unfair discrimination manifests in the process of the harassment of learners, especially of females. The Constitutional Court ${ }^{36}$ has found that discrimination based upon sex and gender principally means treating people

\footnotetext{
32 Prinsloo 2006 SAJE 305.

33 Human Rights Watch 2001 www.hrw.org para 1.

34 Mawson Weekly Mail and Guardian 3.

35 Prinsloo 2006 SAJE 307.

36 Prinsloo v Van der Linde 19976 BCLR 759 (CC) para 31.
} 
differently thereby impairing their dignity as human beings, who are equal regarding their dignity.

Unfair discrimination usually manifests in combination with some kind of power over the harassed, although this is not a legal prerequisite. In education it is perceivable that educators have some or other kind of power over learners. Power has been described as:

a) Legitimate power (position power)

This refers to the official authority delegated to an employee (educator) whereby he or she may legitimately expect any subordinate, not necessarily a fellow employee, to adhere to lawful instructions.

b) Power by reward

This refers to instances where promotion and/or merit recognition may be withheld by exercising authority over the granting thereof. In relation to education this typically refers to sexual favouritism where only those will be rewarded who respond to sexual advances. This reward often takes the form of financial rewards or support to impoverished families, whereas the rejection of such advances would lead to further hardship for the families. ${ }^{37}$

\section{c) Coercive power}

This refers to instilling fear, either psychological or physical, in subordinates or even schoolchildren. Often boys are the perpetrators here due to the patriarchal attitude in our society.

\section{How is sexual harassment managed in the learning environment in South Africa?}

Various acts protect learners against the misuse of power by educators but seem to be ineffective or insufficient to protect victims.

37 Venter, Chikanga and Hansen Citizen 3. 
Sexual harassment in the classroom is managed in terms of section 9 of the Constitution. In education it refers to the opportunity girls/boys must be afforded to be treated equally in schools, free from sexual harassment in any of the ways it can present itself. All learners have the right to equal schooling, ${ }^{38}$ the right not to be unfairly discriminated against, ${ }^{39}$ the right of protection of dignity and integrity, ${ }^{40}$ the right to freedom, ${ }^{41}$ the right to privacy $^{42}$ and the right to a safe environment. ${ }^{43}$ Learners under the age of 18 have the additional right to be protected against abuse. ${ }^{44}$ Sexual harassment infringes upon each and every one of these rights granted by the Constitution.

Section 3 of the South African Schools Act ${ }^{45}$ makes provision for compulsory school attendance. Section 5 of the same act guarantees equal access to public schools. Section 8 provides for a code of conduct to be adopted that must be aimed at establishing a disciplined and purposeful school environment, dedicated to the improvement and maintenance of the quality of the learning process. In ensuring discipline and safeguarding the interests of learners, the code should clarify the standards for learner and educator behaviour and allow for disciplinary action to be taken in instances of misconduct, thereby protecting learners and staff against dangers such as sexual harassment. A disciplined and purposeful school environment may be defined as one that is free of violence and danger, inclusive of sexual harassment as a form of violence. ${ }^{46}$

The Children's Act ${ }^{47}$ protects children's rights and Regulations to the South African Schools $A c t^{48}$ further place an obligation on educators to report any form of maltreatment of children to social welfare or the police, which in itself prohibits the sexual harassment of children at school either by educators or by other learners.

38 Section 29 Constitution of the Republic of South Africa, 1996 (reference hereafter: Constitution).

39 Section 9 Constitution.

40 Section 10 Constitution.

41 Section 12 Constitution.

42 Section 14 Constitution.

43 Section 24 Constitution.

44 Section 28 Constitution.

45 South African Schools Act 84 of 1996.

46 Prinsloo 2006 SAJE 309.

47 Children's Act 38 of 2005.

48 Paragraph 5.2 Regulations to Prohibit Initiation Practises in Schools (GN 1589 in GG 24165 of 3 December 2002). 
The common law further protects learners from misconduct by those in senior positions through the in loco parentis principle, as educators are legally obliged to ensure the physical and psychological safety of learners in their care. ${ }^{49}$

A National Child Protection Register must be kept by the Director-general of the national department responsible for the provision of social development services, as provided for in the Children's Act. ${ }^{50}$ The Register consists of two parts. Part $A^{51}$ serves to record abused or neglected children and Part $B^{52}$ records the names of persons who are found unsuitable to work with children by a children's court, any civil or criminal court or a disciplinary body. ${ }^{53}$

The consequences of the entry of a name in Part B of the register are vast and inter alia lead to such a person being prohibited to manage or operate an institution dealing with children, ${ }^{54}$ to work with or have access to children, ${ }^{55}$ work in any unit tasked with child protection, ${ }^{56}$ or work in any other form of employment or activity as may be prescribed, or foster or be an adoptive parent. ${ }^{57}$

Of great importance is the fact that no person who manages or operates institutions dealing with children may allow such a person to be employed by them, ${ }^{58}$ which places an additional responsibility on schools. If a person's name appears in Part B, such a person has to disclose that fact. ${ }^{59}$

49 Prinsloo 2006 SAJE 309.

50 Section 111, read with s 1 Children's Act 38 of 2005.

51 Sections 113-117 Children's Act 38 of 2005.

52 Sections 118-128 Children's Act 38 of 2005.

53 Section 120(1) Children's Act 38 of 2005. Such a finding can be made regardless whether a person is convicted of any offence or found guilty of any improper conduct, s 120(6). A court must find a person unsuitable to work with children if convicted of murder, attempted murder, rape, indecent assault or assault with the intent to do grievous bodily harm where the victim is a child - S 120(4).

54 Section 123(1)(a) Children's Act 38 of 2005.

55 Section 123(1)(b) (d) and (f). Children's Act 38 of 2005.

56 Section 123(1)(d) Children's Act 38 of 2005.

57 Section 123(1)(c) Children's Act 38 of 2005.

58 Section 123(2) Children's Act 38 of 2005.

59 Section 124 Children's Act 38 of 2005. 
These registers operate to protect children in addition to the The National Register for Sex Offenders created by the Criminal Law (Sexual Offences and Related Matters) Amendment Act. ${ }^{60}$

An amendment to the Employment of Educators Act ${ }^{61}$ ensures that disciplinary action has to be taken against educators who are found guilty of having a sexual relationship with a learner who attends the same school where the educator teaches, even if there was mutual consent, and requires the dismissal such educators from their employ. The same goes for an educator who sexually harasses a learner. The South African Council for Educators (SACE) will ensure that such a teacher's name is struck from the role and that the person may not be employed elsewhere as an educator, not even by private institutions or by any other provider. This principle is guided by section 23(c) of the South African Council for Educators Act. ${ }^{62}$ The relationship between learners and educators is inherently unequal and fragile, and is prone to misuse by the person in whom the power rests.

Section 4 of the Prevention of Family Violence $A c t^{63}$ also instructs educators to report cases of child abuse to the relevant authorities. This section specifically states:

Any person who ... attends to, advises, instructs or cares for any children in circumstances which ought to give rise to reasonable suspicion that such child has been ill-treated, or suffers from any injury, the probable cause of which was deliberate, shall immediately report ...

The Guidelines for the consideration of governing bodies in adopting policies or a code of good conduct for learners state clearly that the absence of sexual harassment is to be ensured as it is the inherent right learners to have a clean and safe environment that is conducive to education. ${ }^{64}$

60 Criminal Law (Sexual Offences and Related Matters) Amendment Act 32 of 2007.

61 Section 17(b), (c) and (d) Employment of Educators Act 76 of 1998 (as amended by the Education Amendment Act, 53 of 2000.

62 South African Council for Educators Act (SACE) 31 of 2000.

63 Prevention of Family Violence Act 133 of 1993.

64 Employment of Educators Act 76 of 1998 (as amended by the Education Amendment Act 53 of 2000). 
According to De Wet and Oosthuizen, it was found in an empirical study on sexual harassment in the school environment done amongst 2414 learners involving 10 different secondary schools in the Potchefstroom area that those school environments could be described as hostile work environments because learners may be precluded from enjoying or participating fully in educational programmes, or the environment is described as intimidating, threatening or abusive. ${ }^{65}$ The sample comprised 55.73 percent boys and 44.27 girls, in the age group 14 to 18 . The majority of the respondents were black (67.25 percent), with whites representing 23.76 percent of the respondents. It was reported in this study that the less serious forms of harassment were more prevalent in the learner-to-learner environment.

More alarming is the fact that 3.82 percent reported sexual touching, 3.37 percent inappropriate touching, 22.70 percent the touching of legs, 3.71 percent the touching of buttocks, 2.11 the touching of breasts and 1.43 percent the touching of sexual organs. Unsolicited and unwelcome kissing by educators was reported by 2.60 percent of the learners. Fifty respondents (2.20 percent) admitted to having been molested by educators and an alarming 9 ( 0.40 percent) of the respondents had been raped or sodomised by their educators. Fifteen respondents admitted to having sexual intercourse regularly and voluntarily with their educators.

The most prevalent defence raised by the educators was mutual consent, which can never be considered true consent:

Even assuming that an adolescent can be sexually attractive, seductive, and even deliberately provocative, it should be clear that no child has equal power to say 'no' to a parental figure or to anticipate the consequences of sexual involvement with a caretaker. In such an unequal relationship the adult (educator) bears sole responsibility for illegal sexual activity with a minor. ${ }^{66}$

5 The legal position in South Africa, where the learning institution acts as the employer

\subsection{Common law and legislation}

65 De Wet and Oosthuizen 2007 TG Supp 87-90.

66 McGrath 2000 www.mcgrathinc.com 1-2. 
Sexual harassment in South African law is seen as an iniuriandi, an infringement of a person's personality and a form of unfair discrimination. ${ }^{67}$ The existence of authority over a sexual harassment victim is not necessary. It often flows from the nature of the workplace but is not a legal prerequisite, not even where educators are seen as employees or where sexual harassment occurs between colleagues and clients or suppliers, doctors and patients, or learners and educators. Often the perpetrator is a person of lower rank or status than the harassed, and this dichotomy should be managed very carefully.

An individual found guilty of sexual harassment in the workplace can be held liable on the grounds of delict, or a contractual liability could follow the harasser, and/or the perpetrator could be charged with criminal offences ranging from assault, indecent assault, rape or attempted rape. The employer could be held liable in common law, ex delicto or ex contractu, possibly be charged with being an accomplice in a criminal trial or be liable in terms of the Employment Equity Act (EEA). Sexual harassment has been defined as:

... unwelcome sexual advances, requests for sexual favours, verbal or physical conduct of a sexual nature, including instances where such favours or conduct are implicitly or explicitly made a condition of employment, continued employment or promotion. $^{68}$

The Code of Good Practice on the Handling of Sexual Harassment ${ }^{69}$ aims to eliminate sexual harassment in the workplace (in a broad sense) and provides for appropriate procedures to deal with the problem and its consequences. It also encourages and promotes the development and implementation of policies and procedures that will lead to workplaces that are free of sexual harassment. ${ }^{70}$ From this it is clear that the objective of the Code is to eradicate sexual harassment from the workplace. It gives guidance not only to what could constitute harassment but also affords a wide scope of application, much wider than merely protecting

67 Snyman-Van Deventer and De Bruin 2002 Acta Academica Supplementum 196.

68 Snyman-Van Deventer and De Bruin 2006 Acta Academica Supplementum 209.

69 Item 4 Code of Good Practice on the Handling of Sexual Harassment Cases promulgated by N 1367 in GG 19049 of 17 July 1998.

70 Items 1(1) and (2) Code of Good Practice on the Handling of Sexual Harassment promulgated by Gen N 1357 in GG 27865 of 4 August 2005. 
employees. It also incorporates, amidst others, contractors, clients, job applicants and suppliers. ${ }^{71}$

The Code addresses the lacuna in our law as to what conduct constitutes sexual harassment and distinguishes it from sexual attention by affording a proper definition in item 3:

(1) Sexual harassment is unwanted conduct of a sexual nature. The unwanted nature of sexual harassment distinguishes it from behaviour that is welcome and mutual.

(2) Sexual attention becomes sexual harassment if -

(a) the behaviour is persistent, although a single incident of harassment can constitute sexual harassment; and/or

(b) the recipient has made it clear that the behaviour is considered offensive; and/or

(c) the perpetrator should have known that the behaviour is regarded as unacceptable.

Due to the extremely cosmopolitan nature of South African society, it is of the utmost importance that employers and jurists take note of the guiding principles in this regard. Policies should be drafted in such a way as to create certainty on which types of behaviour would not be tolerated, taking into account the diversity to be managed in the workplace.

The different forms of sexual harassment are described in item 4 of the Code:

(4)(1) Sexual harassment may include unwelcome physical, verbal, or non-verbal conduct, but is not limited to the following examples:

(a) Physical conduct of a sexual nature includes all unwanted physical contact ranging from touching to sexual assault and rape, and includes a strip search by or in the presence of the opposite sex.

(b) Verbal forms of sexual harassment include unwelcome innuendoes, suggestions and hints, sexual advances, comments with sexual overtones, sex-related jokes or insults or unwelcome graphic comments about persons' bodies made in their presence or to them, unwelcome and inappropriate enquiries about a person's sex life and unwelcome whistling at a person or group of persons.

(c) Non-verbal forms of sexual harassment include unwelcome gestures, indecent exposure, and unwelcome display of sexually explicit pictures and objects.

(d) Quid pro quo harassment occurs when an owner, employer, supervisor, member of management or co-employee undertakes or attempts to

71 Item 2 Code of Good Practice on the Handling of Sexual Harassment (Gen N 1357 in GG 27865 of 4 August 2005). 
influence or influences the process of employment, promotion, training, discipline, dismissal, salary increments or other benefits of an employee or job applicant in exchange for sexual favours.

(2) Sexual favouritism exists where a person who is in a position of authority rewards only those who respond to his or her sexual advances, while other deserving employees who do not submit to sexual advances are denied promotions, merit or salary increases. ${ }^{72}$

\section{a) The Common Law}

Under the common law an employer has a duty to provide its employees with a safe and healthy working environment. A breach of this duty, if it results in harm, may lead to an action based on delict against the employer. ${ }^{73}$ It is likely that failure to provide a safe working environment, free of sexual harassment, could lead to termination of the employment contract by the employee and a claim for constructive dismissal. $^{74}$

Sexual harassment has not been recognised as a specific delict in our legal system but any act or omission resulting in an impairment of the physical integrity of a person, inclusive of the good name and dignity of an individual, which would incorporate privacy, feelings and identity, could be seen as a delict if all of the other elements of a delict are present. It would entitle the victim to recovery of nonpatrimonial loss as well as damages for patrimonial loss. In one of South Africa's landmark cases, $J \vee M L t d,{ }^{75}$ the Industrial Court confirmed that sexual harassment indeed violates the right to integrity of the body and personality, which is protected both civilly and criminally.

b) The Constitution of the Republic of South Africa ${ }^{76}$

The Constitution prohibits discrimination against any person on the grounds of gender or sex and confirms a person's right to work in a workplace free of

72 Item 4 Code of Good Practice on the Handling of Sexual Harassment Cases (N 1367 in GG 19049 of 17 July 1998).

73 Le Roux, Orleyn and Rycroft Sexual Harassment 14.

74 Le Roux, Orleyn and Rycroft Sexual Harassment 13.

75 J v M Ltd 198910 ILJ 755 (IC) 7571 I-J.

76 Constitution of the Republic of South Africa, 1996. 
harassment or discrimination. ${ }^{77}$ Sections 9 and 23 specifically allow for the right to equality, which includes the right not to be unfairly discriminated against and the right to fair labour practices. Thus it finds application in the law pertaining to sexual harassment.

It must be noted that sexual harassment is not specifically listed as a prohibited ground in the Constitution. Hence the development of our law in this regard will rely heavily on case law. The omission of sexual harassment as a prohibition seems to be insignificant against the backdrop of gender and sex being specifically listed as prohibited grounds of discrimination. ${ }^{78}$

c) The Labour Relations $A c t^{79}$

This act is the legislative embodiment of the equality principle and gives effect to the fundamental right to fair labour practices. Any infringement thereof will be dealt with in terms of the Labour Relations Act $^{80}$ In a recent 2008 matter, PSA on behalf of Mthembu, ${ }^{81}$ the accused was discharged from duty after a hearing based on allegations of sexual harassment of a subordinate was proved against the accused employee.

d) The Employment Equity Act (EEA) ${ }^{82}$

This act embodies the legislative enactment of the right to equality as embodied in the Constitution. Sexual harassment in the workplace falls under the auspices of the EEA, which specifically cites sexual harassment as being prohibited, linking it to unfair discrimination. This promotes equal opportunity and fair treatment in employment through the elimination of unfair discrimination and the implementation of affirmative action programmes. Section 6(3) of the EEA states clearly that harassment constitutes unfair discrimination and cannot be justified if one of the grounds listed in section $(6)(1)$ is present. It must be noted that the grounds listed in

77 Snyman-Van Deventer and De Bruin 2002 Acta Academica Supplementum 196.

78 Ntshabo v Real Security CC 200324 ILJ 2341 LC 2377D-E.

79 Labour Relations Act 66 of 1995.

80 Le Roux, Orleyn and Rycroft Sexual Harassment 15.

81 PSA on behalf of Mthembu v Dept. of Health 2008 JOL 21638.

82 Employment Equity Act 66 of 1995. 
section (6)(1) are not the same or similar to those stated in section 36(1) of the Constitution.

The requirements in terms of section 60 of the EEA were recently dealt with in the Mokoena and $A v$ Garden Court Art case ${ }^{83}$ in which it was stressed that an employer could not be held liable under this act if only one instance of sexual harassment had occurred. Liability followed the employer only if the conduct of the harasser had been brought to the attention of the employer and if the harassment continued as a result of failure of the employer to take the necessary steps to prevent, eliminate, or prohibit sexism or genderism, which was not applicable in this matter.

e) The Promotion of Equality and Prevention of Unfair Discrimination Act $(\text { PEPUDA })^{84}$

The prohibitions in this act are applicable to sexual harassment matters outside the working environment and embody the equality principle in our constitution. PEPUDA specifically refers to sexual harassment as being prohibited. The act regulates those instances where sexual harassment as a form of unfair discrimination presents itself by or to a person other than the employer or employee. ${ }^{85}$ Several other statutes ${ }^{86}$ aim to ensure a safe working environment for employees and third parties. It must be kept in mind that a school also serves as a workplace.

\section{f) Code of Conduct}

Since sexual harassment is not defined by the Employment Equity Act, a Code of Good Practice on the Handling of Sexual Harassment ${ }^{87}$ has been published in terms of the Labour Relations Act. The 2005 Code of Good Practice on the Handling of Sexual Harassment advises on and is a guiding tool for understanding the concept

83 Mokoena v Garden Court Art (Pty) Ltd 200829 ILJ 1196 (LC) 1196.

84 Promotion of Equality and Prevention of Unfair Discrimination Act 4 of 2000.

85 Le Roux, Orleyn and Rycroft Sexual Harassment 18.

86 These include the Occupational Health and Safety Act 85 of 1993, the Compensation for Occupational Injury and Diseases Act 130 of 1993 (as amended) and the Protected Disclosures Act 26 of 2000.

87 Code of Good Practice on the Handling of Sexual Harassment (N 1357 in GG 27865 of 4 August 2005). 
of sexual harassment. It will shape the law in this matter in future, even though it creates no subjective rights in itself. ${ }^{88}$

In 2008 in the Maepe ${ }^{89}$ case the accused was found not guilty on the grounds that the conduct complained of was not persistent and it was not made clear, as required, that the conduct was unacceptable to the complainant. From this judgement it is evident that the Code of Good Practice is followed by the judiciary. Although it is merely a guide, its requirements have to be adhered to for a verdict of guilty to be warranted.

\subsection{Employer liability in South African law}

The liability of an employer for sexual harassment by an employee is regulated by the doctrine of vicarious liability and by section 60 of the Employment Equity Act. ${ }^{90}$ Liability of this nature is derived from the common law. It is based on the adage that the employer is liable for ensuring a safe working ${ }^{91}$ environment in which employees (educators) are not exposed to actual or looming physical or mental harm. The employer, who stands in an employment relationship with the harassed, is prima facie vicariously liable ${ }^{92}$ solely on the grounds of the employment relationship if sexual harassment is proved to have occurred in the workplace.

In Grobler $v$ Naspers ${ }^{93}$ the court found vicarious liability on the basis that the common law had to be developed as sanctioned by section 173 of the Constitution and the inherent power of the Supreme Court. The court ruled that vicarious liability existed because it was a constitutional duty to protect the right to dignity and the right to freedom of security.

Because employment has evolved into a blend of tasks and relationships that extend beyond the principal parties to the contract, it would be unrealistic to expect that such relationships may not be improperly conducted and that employers should

88 Le Roux, Orleyn and Rycroft Sexual Harassment 19.

89 Maepe v CCMA 2008 JOL 21837 LAC.

90 Le Roux, Orleyn and Rycroft Sexual Harassment 75.

91 Snyman-Van Deventer and De Bruin 2002 Acta Academica Supplementum 211.

92 Stadsraad van Pretoria v Pretoria Pools 19901 SA 1005 (T) $1007 \mathrm{H}$.

93 Grobler v Naspers BPK 20045 BLLR 455 (C) 527. 
be held liable for the conduct of an employee if the requirements of the commissioning of a delict are present. $^{94}$

Liability in terms of section 60 of the EEA is driven by its purpose, which is to penalise the employer for failing to address equity in the workplace. The purpose of section 60 is to punish an employer when an employee contravenes a provision of the EEA whilst at work and not to punish an employer for a delict. Sexual harassment by or of independent third parties such as contractors, suppliers, clients and learners will not be covered by this section. ${ }^{95}$

Sexual harassment by an employee is a contravention of the EEA. When it occurs at work and the prerequisites have been met, section 60 of the EEA will come into play. In the sexual harassment sense it means that an employer will be held liable if one employee sexually harasses another employee at work. It must also be said that "workplace" has been defined in its broader sense, incorporating circumstances where the employee is travelling or attends work-related functions. It does not refer to a physical location only. ${ }^{96}$ It is not a prerequisite that the employer should have been informed of the sexual harassment for this section to take effect. As liability is not strict under this section it could be avoided by the employer in two ways:

a) The employer should, once he becomes aware of the sexual harassment, consult all of the parties and take the necessary steps to eliminate the said conduct and comply with the EEA. If this is not done, the employer will be deemed to have contravened section 60 of the EEA and will become liable for the said contravention. ${ }^{97}$ This seems to be the reactive reward as opposed to the following, which is clearly meant as a reward for the proactive employer.

b) If the employer is able to prove that he did all that was reasonably practicable to ensure that the employee would not act contrary to the EEA. ${ }^{98}$

94 Le Roux, Orleyn and Rycroft Sexual Harassment 91.

95 Le Roux, Orleyn and Rycroft Sexual Harassment 95.

96 Le Roux, Orleyn and Rycroft Sexual Harassment 94-95.

97 Le Roux, Orleyn and Rycroft Sexual Harassment 96.

98 Le Roux, Orleyn and Rycroft Sexual Harassment 96. 
What seems to be meant by the terminology "reasonably practicable" is not entirely clear. South African case law under this section is lacking, but would most probably entail the drafting and communication of a full programme on sexual harassment in the specific workplace. The test in this regard should be if the precautions were reasonable rather than ideal, as the Act does not set out the factors to be taken into account in determining if reasonable precautions had been taken. ${ }^{99}$ The EEA does not deprive the employee of common law remedies against the employer and no limit has been placed on the amount of compensation or damages that can be claimed, unlike the Labour Relations Act.

Delictual liability is embedded in the principle that the harasser or his/her employer could be sued due to ex delicto damages, or be sued for reparation to compensate for damage or loss caused to the harassed. Income forfeited could be recovered as well as a plethora of other damages, e.g. an award for the loss of a promotion opportunity, or psychological harm. ${ }^{100}$

An ex contractu claim can also follow the employer, as the harassed could sue for breach of contract if the harassment has led to unfair dismissal of the employee.

The employer could be charged as an accessory to the crime if a criminal charge is laid and he/she encouraged the crime or knew of the crime but failed to act to stop such harassment, as it is the employer's duty to stop any harassment of its employees. $^{101}$

\section{Sexual harassment in the education sector in America}

Tertiary education plays a vital role in ensuring economic security for the youth, especially females, but these institutions in America still display a tendency toward bias and harassment which has a negative influence on students' receiving a fair education.

99 Le Roux, Orleyn and Rycroft Sexual Harassment 96.

100 Snyman-van Deventer and De Bruin 2002 Acta Academica Supplementum 213.

101 Snyman-van Deventer and De Bruin 2002 Acta Academica Supplementum 213. 
Most college students experience some type of sexual harassment, often during their first year. Ranging from unwanted sexual remarks to forced sexual contact, these experiences cause students, especially female students, to feel upset, uncomfortable, angry and disappointed in their college experience. ${ }^{102}$

In a survey done in 1994 of second-year students who were selected randomly from an American Medical Association database, 63 percent of female respondents reported sexual harassment during their internship. ${ }^{103}$ The 2005 investigation, which is nationally representative of undergraduate students, performed by the Association of University Women Educational Foundation, found that nearly two thirds of college students experienced some sort of sexual harassment. In contrast, fewer than 10 percent told a friend or other person and an even smaller fraction formally reported the sexual harassment. ${ }^{104}$ More than a third encountered sexual harassment in their first year, the majority reporting non-contact behaviour, but nearly a third experienced some form of physical harassment such as touching, grabbing, or being forced to do something sexual. These types of behaviour are more common at larger universities, at four-year institutions and private colleges. ${ }^{105}$ The study also found that men and women were equally likely to be harassed but that their responses differed in that female students were more likely to be upset and feel embarrassed by the harassment. They also felt more worried, less confident, confused, or conflicted about their identities, and they were more likely to alter their behaviour subsequent to having been sexually harassed. Female victims also found it harder to concentrate in class and to sleep as a result of sexual harassment. Lesbian, gay, bisexual and transgendered students were found to be harassed more often than others. For the most part it was found that white, black and Hispanic students perceived and reacted to sexual harassment in similar ways. ${ }^{106}$ It was also found that men were more likely to harass than females. Half of male students admitted to having sexually harassed someone in college whilst a third of female students admitted to having harassed someone in college.

102 Hill and Silva 2005 www.aauw.org iii. 103 Jorgenson and Wahl 2000 Harv Rev Psychiatry 95.

104 Hill and Silva 2005 www.aauw.org iii.

105 Hill and Silva 2005 www.aauw.org 2-3.

106 Hill and Silva 2005 www.aauw.org 3. 
The position in schools is even more alarming. According to a study done by Walsch in $2007^{107}$ it was found that sexual harassment in high schools was a severe problem. The study done in 2007 measured the prevalence of sexual harassment in high schools. Students were asked to report only on incidents of sexual harassment that had happened in the preceding two weeks and had happened to themselves. Of the 1,582 students interviewed, 75 percent of the students reported having been sexually harassed over the last two weeks before the interviews were conducted. 7 percent reported sexual behaviour of a physical nature and 15 percent reported having been very upset by such harassment. ${ }^{108}$ According to this study harassment happened most in the hallways ( 7 percent), then the classroom ( 6 percent) and outside the school building on the school grounds ( 4 percent), but only 0.5 percent had reported this to a teacher or other school employee.

As far back as 1993 the American Association of University Women (AAUW) performed a study on the prevalence of sexual harassment in high schools. The AAUW reported that 81 percent of students had experienced or knew of someone who had experienced unwelcome behaviour of a sexual nature at some point in their schooling. Females were harassed most and were the victims of more serious types of sexual harassment than males. Most of the perpetrators were boys or men, and only 9 percent of those had reported being victims. In Canada it was reported that 70 percent of students had been sexually harassed in their school environment. ${ }^{109}$ This shows how old this problem in the education sector really is.

\section{$7 \quad$ The legal position in America}

\subsection{A walk through legislation and case law}

In the US, sexual harassment is deemed to be a type of employment discrimination based upon sex. It is prohibited through Title VII of the Civil Rights Act of 1964, ${ }^{110}$ which proscribes employment discrimination on the basis of race, colour, national origin, religion and sex. This type of harassment has also been described as a

107 Walsh, Duffy and Gallagher-Duffy 2007 Can J Behav Sci 110.

108 Walsh, Duffy and Gallagher-Duffy 2007 Can J Behav Sci 114.

109 Walsh, Duffy and Gallagher-Duffy 2007 Can J Behav Sci 111.

110 Hill and Silva 2005 www.aauw.org 7. 
threat, offer or act of sexual favour in exchange for positive consequences or avoidance of negative consequences. ${ }^{111}$ It was first recognised as a form of sex discrimination in the workplace by the federal court in 1976 in Williams $v$ Saxbe. ${ }^{112}$

Two main forms of sexual harassment are evident:

\section{a) Quid Pro Quo Harassment}

This form of harassment links sexual favours or rebuffs to employment decisions either refusing a promotion or appointment, or declining a deserved raise because of the refusal of sexual advances.

b) Hostile Work Environment

A hostile working environment is more difficult to prove but the EEOC defined it in 1992 as including the telling of unwanted jokes, uttering sexist remarks, or using offensive language. ${ }^{113}$

Sexual harassment in American schools is rife. It has been reported that 85 percent of high school girls and 75 percent of high school boys disclosed that they had been sexually harassed. ${ }^{114}$ The American law strongly distinguishes educator-to-learner harassment from peer sexual harassment. Schools themselves are required to prohibit peer sexual harassment. Fortunately the legal system clearly differentiates horseplay and less serious conduct of a sexual nature from real sexual harassment. Educators are not obliged to protect peers against teasing or horseplay that forms part of normal childhood play.

This differentiation does not exist in the South African legal system and should be addressed in the code of conduct and policy to be formulated by schools in terms of the Schools Act.

Title IX of the Education Amendments of 1972 states:

111 Limpaphayom, Williams and Fadil 2006 Cross Cultural Management 33.

112 Williams v Saxbe 413 F Supp 654 (DCDC 1976) 658.

113 Limpaphayom, Williams and Fadil 2006 Cross Cultural Management 33.

114 Klusas 2003 TFCLCR 94. 
No person in the United States of America shall, on the basis of sex, be excluded from participation in, be denied the benefit of, or be subjected to discrimination under any education programme or activity receiving Federal financial assistance.... ${ }^{115}$

In terms of liability the court found in Gebser v Lago Vista Independent School District $^{116}$ that to be held liable school officials must have had actual notice of a teacher's sexual harassment instead of having only constructive notice. ${ }^{117}$ The concept of "deliberate indifference" was introduced into Title IX legislation, which entailed "something more than mere negligence [but was] something less than acts or omissions for the very purpose of causing harm." ${ }^{118}$ Only if all of these elements were present could liability ensue. This was confirmed in Soper $v$ Hoben, ${ }^{119}$ and in 2004 in Doe $v$ Towne of Bourne ${ }^{120}$ it was confirmed that a three-year statute of limitation had to be adhered to.

It is important to note that in instances of peer sexual harassment, all four factors as set out in the Davis Decision ${ }^{121}$ had to be present for schools to be held liable. This requirement protects not only learners but also schools from liability in instances of less serious types of harassment. ${ }^{122}$ In 2000, the sixth Circuit Court decided in Vance $v$ Spencer County Public School District ${ }^{123}$ what would be regarded as pervasive sexual harassment and elaborated on what would be regarded as objectively offensive, based upon a very clear demonstration of the harassment complained of.

Title VII was designed to encourage the creation of anti-harassment policies and effective grievance mechanisms. It borrows from tort law the "avoidable consequences doctrine" on which grounds an employer can avoid liability by having in place procedures that would identify and eliminate harassment ${ }^{124}$.

115 Klusas 2003 TFCLCR 96

116 Gebser v Lago Independent Schools District, 524 US 274 (1998) 1911.

117 Klusas 2003 TFCLCR 97.

118 Farmer $v$ Brennan 511 US 825 (1994) 1980 item 2.

119 Soper $v$ Hoben $195 \mathrm{~F} 3 \mathrm{~d} 845$ ( $6^{\text {th }}$ Cir 1999) 851.

120 Doe v Town of Bourne 2004 WL 1212075 (D Mass) 10.

121 Davis v Monroe County Board of Education 74 F 3d 1186 ( $11^{\text {th }}$ Cir 1996) item 4.

122 Eckes 2006 Education Digest 37.

123 Stephen Vance $v$ Spencer County Public School District 231 F 3d 253 ( $6^{\text {th }}$ Cir 2000) 259.

124 Marczely 1999 Clearing House 317-318. 
More recently in Kampmier ${ }^{125}$ the requirements for an action based upon sexual harassment, creating an offensive working environment, were set out again as being whether:

i. the claimant was subjected to unwelcome harassment;

ii. the sexual harassment was based upon sex;

iii. the sexual harassment was sufficiently severe and pervasive to alter the conduct of the employee and create a hostile or abusive working environment;

iv. there was a basis for employer liability.

Liability for the employer could ensue only once all of these requirements had been met.

\subsection{Employer liability in American law}

With American law pertaining to sexual harassment leading the legal development in this field, we need to take cognisance especially of employer liability in the USA legal system. ${ }^{126}$

A potential reason for the increase in sexual harassment in American schools is the confusion about the legal responsibility to respond to such claims. Schools have to contend with two different legal standards:

a) The constructive notice standard to protect themselves from losing federal funding.

In this instance a school can be found liable and lose its federal funding if the school knew or should have known about peer sexual harassment.

b) The actual notice standard to protect themselves from private law suits.

125 Kampmier v Emeritus Corp $472 \mathrm{~F} 3 \mathrm{~d} 930$ ( $7^{\text {th }}$ Cir 2007) $940-943$.

126 Shrout v Black Clawson Co 689 F Supp 774 (SD Ohio 1988) 774-775. 
In this instance a school can be found liable and thus owe money damages only if the school knew about the sexual harassment by peers. ${ }^{127}$

As a result, schools end up either under-protecting harassed employees or overpunishing perpetrators. In the first sexual harassment case dealing with peer sexual harassment the court held in Davis $v$ Munroe Country Board of Education, ${ }^{128}$ with reference to Gebser $v$ Lago, ${ }^{129}$ that liability for schools with regard to peer sexual harassment under article IX would follow only if:

a) a school official was deliberately indifferent to the harassment

b) the harassment was so severe, pervasive and objectively offensive that it barred the victim's access to education.

The only defence available for schools is to prove that they took timeous, reasonable and effective corrective action and maintained it until the sexual harassment was stopped, as was intended by Title IX. ${ }^{130}$

In all instances, if the employer had a policy in place, and if managers and supervisors were able to detect sexual harassment and deal with it appropriately, especially if the employer's response to detected sexual harassment was reasonable and directed at terminating sexual harassment in the workplace, liability could be avoided. The establishment of an entire sexual harassment programme is suggested to avoid liability, including awareness creation, workplace discussions, the design of an effective policy, and clear and well communicated procedures.

For succeeding in a claim based upon quid pro quo harassment, the claimant would have to prove that:

i. he/she was a member of a protected class

ii. he/she was subjected to unwelcome sexual advances

iii. the advances were based upon gender

127 Klusas 2003 TFCLCR 91.

128 Davis v Monroe County Board of Education 526 US 629 (1999) 1186.

129 Gebser v Lago Vista Independent Schools District 524 US 274 (1998) 1193.

130 Klusas 2003 TFCLCR 105. 
iv. submission to the demand was made a condition of receiving job benefits or avoiding job detriments. ${ }^{131}$

There are different requirements for claims of sexual harassment when the claimant claims a promotion- see Henson $v$ City of Dundee. ${ }^{132}$

For a claim based upon the existence of a hostile working environment, the claimant has to show on a balance of probabilities that:

i. she/he was a member of a protected class

ii. he/she was subjected to unwelcome sexual harassment affecting a term, condition, or privilege of employment and

iii. the employer knew or should have known about the harassment and failed to take appropriate remedial action. ${ }^{133}$

In addition to the above, the claimant must also show that the harassment is abusive and serious enough to alter working conditions. A "reasonable woman test" was created by some federal courts to take into account the perspectives and experiences of women, which produced a great variety of results. Although it was later suggested that the reasonable standard should be broad enough to include both women and men, and that the purpose would be best served if the concept of reasonableness was replaced by the concept of "respect", the courts are still using the old concept of "reasonableness" to establish guilt. ${ }^{134}$

With regards to the liability of a school district as an employer, the ruling in Ellerth ${ }^{135}$ makes it imperative for all employers to have a sexual harassment policy in place and to act promptly whenever inappropriate behaviour is brought to their attention. As stated above, the employer is subject to vicarious liability if an actionable hostile environment was created or if no tangible employment action were taken. The employer may raise the defence that:

131 Cram v Lamson and Session Co 49 F 3d 466 (8th Cir 1995) 473 item 16.

132 Henson $v$ City of Dundee 638 F 2d 897 (11 $1^{\text {th }}$ Cir 1982) 903.

133 Henson v City of Dundee 638 F 2d 897 (11 ${ }^{\text {th }}$ Cir 1982) 903.

134 Snyman-Van Deventer and De Bruin 2002 Acta Academica Supplementum 208.

135 Ellerth v Burlington Industries 912 F Supp 1101 (ND III 1996) 1104, 1124. 
- $\quad$ it exercised reasonable care to prevent and correct promptly any sexually harassing behaviour or

- the claimant unreasonably failed to take advantage of any preventative or corrective opportunities provided by the employer to avoid harm or otherwise. $^{136}$

If a school district is sued for creating a hostile environment stemming from sexual harassment, it can avoid liability if it can prove that it had a sexual harassment policy in place and that the plaintiff employee did not use such. ${ }^{137}$

In Franklin v Gwinnett County Public Schools (1992) ${ }^{138}$ a parallel was drawn between teacher-to-student sexual harassment and supervisor-to-subordinate harassment. It concluded that both were viewed as a type of discrimination, stressing that the same rules applied to both types of harassment. The Supreme Court, and not Congress, interpreted Title IX to allow for damages for teacher-tostudent harassment, and the Gebser ${ }^{139}$ case distinguished between harassment liability under Title IX and Title V11. Title IX is in essence a contract between the federal government and educational institutions, in which federal funding is conditional upon the premise that the recipient would not discriminate on the basis of gender. It discourages discrimination at federally funded institutions by threatening to withhold funding if discrimination occurs. ${ }^{140}$

In an article by Karen L Michaelis aptly titled "Title IX and Same-Gender Sexual Harassment" ${ }^{141}$ she discusses the grounds on which school liability has failed when instituted under the normal Title VII and applied under Title IX. Courts have found that Title VII applies only to the employment context. As children or students are not employees, they are doomed to fail with an action for damages on the grounds of sexual harassment if it is instituted under Title VII. The 1996 ruling in Davis ${ }^{142}$

136 Ellerth v Burlington Industries 912 F Supp 1101 (ND III 1996) 1124.

137 Marczely 1999 Clearing House 318.

138 Franklin v Gwinnett County Public Schools 503 US 60 (1992) 1037.

139 Gebser v Lago Vista Independent School District 524 US 274 (1998) 1992.

140 Marczely 1999 Clearing House 316.

141 Michaelis 2000 BYU Educ \& LJ 47-98.

142 Davis v Munroe County Board of Education 74 F 3d 1186 (11 ${ }^{\text {th }}$ Cir 1996) $1195-1196$. 
created a stricter framework for school liability based upon sexual harassment. This new standard makes it easier for courts to protect the resources of school districts at the expense of student victims of sexual harassment. Very few students have ever been successful when claiming damages because of the requirement that school officials had to have knowledge of the harassment. Although it is true that parents expect their children to be safe from sexual harassment when they send them to school, it is unlikely under the existing liability requirements that students can prove that the school knew of the harassment but failed to take the necessary steps to stop or prevent it, as it is unclear who should have known of the harassment. ${ }^{143}$ Thus the problem persists in schools and tertiary institutions. We should learn from these lacunae to enable us to develop effective policies in this regard.

\section{The effect of sexual harassment in the workplace and in education}

The number of victims who take formal action against their harassers stands in stark contrast to the percentage of victims who suffer emotional distress as a result of sexual harassment in the workplace. It is estimated that only 15 percent of sexual harassment victims file any type of formal complaint and only 6 percent take formal action against their perpetrators. ${ }^{144}$ The estimate of harm can easily be as high as 90 percent. Well-known side effects of sexual harassment reported in professional literature include somatic symptoms such as disturbed sleep, nightmares, headaches, fatigue, nausea, neck pain, back pain, gastrointestinal disturbances, loss of appetite and weight loss. Work-related complaints associated with sexual harassment can manifest as increased absenteeism, poor work performance and poor work evaluation. Psychological effects include a lack of self-esteem, irritability, isolation, depression, anger, guilt, fear, frustration and helplessness. Among the diagnoses made in cases treated by psychiatrists arising from sexual harassment in the workplace are adjustment disorders, major depression, and anxiety disorders. ${ }^{145}$ Employers and educators should be on the lookout for such symptoms as they could be indicative of sexual harassment that calls for immediate action.

143 Michaelis 2000 BYU Educ \& LJ 86-98.

144 Jorgenson and Wahl 2000 Harv Rev Psychiatry 97.

145 Jorgenson and Wahl 2000 Harv Rev Psychiatry 97. 
Where sexual harassment occurs on campus, it has been shown to cause students to avoid certain places on campus, change their schedules, drop classes or activities or change their lives to avoid sexual harassment. ${ }^{146}$

For colleges and universities, sexual harassment can be costly and damage their reputations, but the emotional and academic wellbeing of students should be the highest priority. Sexual harassment can damage students' wellbeing, provoke and exacerbate conflict among students, and contribute to a hostile learning environment. ${ }^{147}$

Students have reported that harassment negatively influenced their schoolwork and performance. It has been shown that students are burdened by the psychological effects of sexual harassment and that they are more likely to be self-conscious, more doubtful about ever having a happy romantic relationship, embarrassed, afraid, less confident and confused about themselves than their peers. ${ }^{148}$ Students who perpetrate this kind of behaviour sometimes become adults who continue sexually harassing others. ${ }^{149}$ Nearly half of the students who reported sexual harassment were at risk of harm to their personal development. They were less talkative in class and their performance plummeted. Interestingly, it was found that for men sexual harassment was related to the risk of illness, injury, or assault, but not for women. The reality of assault stemming from sexual harassment as an occupational risk has to be managed, as research prior to this study ${ }^{150}$ had not established a link between sexual harassment and assault at the workplace.

According to Espekhage and Holt, ${ }^{151}$ in a study published in 2007 on dating violence and sexual harassment among middle and high school students in the USA, it was confirmed that 81 percent of students experienced some form of sexual harassment during their school lives. 6 out of 10 experienced it occasionally, and a quarter of them dealt with sexual harassment on a regular basis. Physical harassment was reported by 58 percent of students, and 48 percent were upset by an experience of some form of sexual harassment. ${ }^{152}$

\footnotetext{
146 Hill and Silva 2005 www.aauw.org 4.

147 Hill and Silva 2005 www.aauw.org 2-3.

148 Walsh, Duffy and Gallagher-Duffy 2007 Can J Behav Sci 111.

149 Walsh, Duffy and Gallagher-Duffy 2007 Can J Behav Sci 111.

150 Rospenda, Richman and Others $2005 \mathrm{~J}$ Bus Psychol 107.

151 Espelage and Holt 2007 Youth Adolescence 799-811.

152 Espelage and Holt 2007 Youth Adolescence 799-800.
} 
Adolescence in itself presents a number of challenges that entail social, emotional and academic development. It has been proved that students who experience sexual harassment in the first phase of early adolescence find it more difficult than those experiencing it in the later part of adolescence. ${ }^{153}$

In the light of the findings that most victims of sexual harassment have been subjected to extended patterns of sexual harassment rather than a single incident, ${ }^{154}$ the health of employees should be a top priority for employers, schools and tertiary institutions.

\section{Possible ways of steering clear of liability and ensuring a safe learning and working environment}

According to Limpaphayom, Williams and Fadil it is evident that the best way to address sexual harassment in the workplace is to establish effective policies. Organisations have to establish and communicate effective policies and procedures, interventions and training programmes to combat the problem. ${ }^{155}$ Changes in organisational culture also need to be introduced to effectively address the problem in the workplace. The most important part of effective policy would be to clearly define sexual harassment behaviour. Managers and employees need to understand what types of behaviour constitute sexual harassment to make provision for different perceptions of what constitutes sexual harassment.

A study done in the UK on the effectiveness of sexual harassment policies in the UK and Canada, reported by Thomas, has clearly indicated that a policy based on a "consultative" approach had the better effect regarding the number of cases reported per year. The universities where the sexual harassment policies were developed from the "top down" reported fewer incidents per year and had the highest incidence of the non-reporting of sexual harassment (83 percent). ${ }^{156}$

153 Gruber and Fineran 2007 Violence against Women 34.

154 Fitzgerald 1997 J Appl Psychol 401-402.

155 Limpaphayom, Williams and Fadil 2006 Cross Cultural Management 33.

156 Thomas 2004 Brit J Soc Educ 152. 
It is of the utmost importance that user-friendly reporting procedures be instilled by organisations, especially in schools and tertiary institutions. An informal network of advice is not sufficient to combat the problem of sexual harassment in institutions. $A$ proactive approach at universities has also proved to deliver far better results than a reactive approach. 69 percent of a total of 16 universities reporting more than five cases per year had implemented a consultative/network strategy while only nine percent of the universities used a top-down/network approach.

The desire to protect their image often causes institutions to ignore this persistent problem. This is especially the case in education, where learners are entrusted to educators. Although the sensitivity aspect can be understood, it should not be an obstacle to the prevention of sexual harassment in the workplace.

Sexual harassment is a multifaceted and complex matter which is interrelated with the practices at school on a daily basis ... and the interrelationships between sexual harassment and other issues, such as lesbophobia, racism, ageism and classism, are of major significance in the way that this practice in schools remains silenced and marginalised. ${ }^{157}$

This problem cannot be managed unless it is brought into the open, effective policies are developed, and full programmes similar to the HIV initiative are embarked upon.

A study conducted at five UK medical universities and reported in 2007 offered a remarkable solution to sexual harassment in the faculty where all knew what was happening but no one took action:

They don't need a better way for people to report it, they need to start at the top and make impression that this is wrong, and infuse this into people because they've been doing it for so long they think it's fine and then residents see the attending acting this way and they think 'oh, it's acceptable' and it's a kind of vicious cycle because no one at the top says 'NO, you can't make comments like that..'158

A school climate supportive of sexual harassment is directly associated with increases of sexual harassment and negative psychological, work and health

157 Robinson 2000 Studies in Cultural Politics of Education 83.

158 Wear, Aultman and Borges 2007 Teaching and Learning in Medicine 24. 
outcomes. ${ }^{159}$ Therefore it is imperative in the education sector that an effective and well documented sexual harassment programme be developed to stipulate the wrong behaviour to correspond with the Codes of Conduct required as per the legislation discussed infra. The unethical conduct of educators and learners should be treated with disdain, and Teacher Unions could play a huge role here. ${ }^{160}$

The Department of Education should develop or attain programmes to sensitise all partners in education about ways to protect, promote and fulfil human rights in education. ${ }^{161}$

It is further suggested that the following be addressed in the formulation of policies and codes of conduct pertaining to schools: ${ }^{162}$

a) Use language that clearly and unambiguously prohibits sexual conduct between and among students and staff.

b) Include examples of unacceptable conduct and behaviour.

c) Outline possible sanctions and procedural safeguards which should:

i) include clear and specific language on how, and with whom, an aggrieved party can file a complaint

ii) establish time frames within which a complaint should be filed and disciplinary action taken

iii) provide details about the investigatory process

iv) identify who may conduct an investigation and/or hearing

v) explain avenues of appeal that may be available

vi) include assurance to safeguard the privacy rights of both the accused and victim.

d) It is of the utmost importance to afford counselling and assistance to the victims of sexual harassment. Even the perpetrator should be sent for counselling in the light of the in loco parentis principle and the effect that sexual harassment has on victims, whom schools are supposed to protect.

159 Ormerod, Collinsworth and Perry 2008 PWQ 113-125 especially on 115.

160 Prinsloo 2006 SAJE 315.

161 Prinsloo 2006 SAJE 315.

162 Russo 2001 Education and the Law 69-74. 
If the above suggestions are followed the liability of schools may be diminished. Consequently, the education sector should have more time to devote its efforts to providing the best possible education to all children. ${ }^{163}$

\section{Conclusion}

Both educational institutions and the workplace are contexts especially conducive to sexual harassment as they present real possibilities for people to abuse their power. The power model exists both in the education field and in the workplace. It must be noted that the school is the preparation ground for tomorrow's employees and employers. If the supervisor - who in the case of the education sector is the educator - misuses this power in an already fragile environment, the misuse creates a breeding ground for the future misuse of power and the continuation of sexual harassment, as various studies have shown.

International experience does not differ from South African experience in respect of the prevalence and severity of the harassment. With more than two thirds of American female students having experienced sexual harassment whilst studying, it is clear that the prevalence is indicative of the magnitude of the problem.

Cultural factors and the effect thereof on the perceptions of sexual harassment need to be further researched in South Africa, more than anywhere else in the world, due to the cosmopolitan nature of our country. Not only do we need to deal communicate in eleven official languages but vast cultural differences come into play as well. These factors present barriers to the effective management of sexual harassment in education. In the absence of a clear and unambiguously formulated harassment policy with a policy statement confirming zero tolerance for sexual harassment, this problem will not be uprooted. Females in particular will remain the victims of their sexuality, thus being denied the fundamental rights guaranteed in the Constitution.

Radical amounts of money have been paid by companies in America after they had been sued in their capacity either as educational institutions or as employers. In 
2007, according to the EEOC 49, nine million dollars was paid out as monetary benefits following sexual harassment suits. ${ }^{164}$ No statistics are available for South Africa in this regard.

Due to the absence of proper and reliable statistics, the magnitude of the problem has been underestimated, and it has been treated like any other compliance issue in the workplace and in education. Only recently, due to media coverage and a report of the UN, the problem of the misuse of power in schools has been addressed via legislation in South Africa.

The prevention of sexual harassment in education should be seen as an educational challenge. The focus should be shifted from the avoidance of liability to the need to educate learners and educators on the effects of sexual harassment, the myths surrounding sexual harassment, and the role that culture plays in the perception of sexual harassment.

164 US EEOC [date unknown] eeoc.gov. 


\section{Bibliography}

Cherner-Ranft 2003 NW U L Rev

Cherner-Ranft M E "The Empty Promise of Title IX: Why Girls Need Courts to Reconsider Liability Standards and Pre-emption in School Sexual Harassment Cases" 2003 NW U L Rev 1891-1926

De Wet and Oosthuizen 2007 TG Supp

De Wet A and Oosthuizen I "Opvoeder-tot-leerder seksuele teistering in sekondêre skole" 2007 TG Supp 7(4) 86-102

Dziech and Weiner Lecherous Professor

Dziech BW and Weiner L The Lecherous Professor: Sexual Harassment on Campus $2^{\text {nd }}$ ed (University of Illinois Press Champaign 1994)

Eckes 2006 Education Digest

Eckes S "Reducing peer harassment in schools" 2006 The Education Digest $71(7) 36-41$

Espelage and Holt 2007 Youth Adolescence

Espelage DL and Holt M "Dating Violence and Sexual Harassment across the Bully-Victim Continuum among Middle and High School Students" 2007 Youth Adolescence 799-811

Eyre 2000 Gender and Education

Eyre L "The Discursive Framing of Sexual Harassment in a University Community" 2000 Gender and Education 12(3) 293-307

Fitzgerald 1997 J Appl Psychol

Fitzgerald LF "Job-Related and Psychological Effects of Sexual Harassment in the Workplace: Empirical Evidence from Two Organisations" $1997 \mathrm{~J}$ Appl Psychol 401-415

Gruber and Fineran 2007 Violence against Women 
Gruber JE and Fineran S "The Impact of Bullying and Sexual Harassment on Middle and High School Girls" 2007 Violence against Women 627-643

Jorgenson and Wahl 2000 Harv Rev Psychiatry

Jorgenson LM and Wahl KM "Workplace Sexual Harassment: Incidence, Legal Analysis, and the Role of the Psychiatrist" 2000 Harv Rev Psychiatry 8(2) $94-98$

Klusas 2003 TFCLCR

Klusas JA "Providing Students with the Protection they Deserve: Amending the Office of Civil Rights Guidance or Title IX to Protect Students from Peer Sexual Harassment" 2003 TFCLCR 8(1) 91-116

Le Roux, Orleyn and Rycroft Sexual Harassment

Le Roux R, Orleyn T and Rycroft A Sexual Harassment in the Workplace: Law, Policies and Processes (LexisNexis Butterworths Durban 2005)

Limpaphayom, Williams and Fadil 2006 Cross Cultural Management Limpaphayom W, Williams RJ and Fadil PA "Perceived differences in sexual harassment between business school students in the US and Thailand" 2006 Cross Cultural Management: An International Journal 13(1) 32-42

Marczely 1999 Clearing House

Marczely B "Mixed Messages: Sexual Harassment in Public Schools" 1999 The Clearing House 315- 318

Mawson Weekly Mail and Guardian

Mawson N 'State liable for school rape' Weekly Mail and Guardian 15 January 20043

Michaelis 2000 BYU Educ \& LJ

Michaelis KL "Title IX and Same-Gender Sexual Harassment: School District Liability for Damages" 2000 BYU Educ \& LJ 47-89 
Ormerod, Collinsworth and Perry 2008 PWQ

Ormerod A, Collinsworth L and Perry LA "Critical climate: relations among sexual harassment climate and outcomes for girls and boys" 2008 PWQ 113125

Prinsloo 2006 SAJE

Prinsloo S "Sexual Harassment and Violence in South African Schools" 2006 SAJE 305-318

Ristow Sexual Harassment

Ristow L Sexual Harassment in Employment (LLM dissertation UPE 2004)

Robinson 2000 Studies in Cultural Politics of Education

Robinson K ''Great Tits, Miss!' The silencing of male students' sexual harassment of female teachers in secondary schools: a focus on gendered authority discourse" 2000 Studies in Cultural Politics of Education 21(1) 75-90

Rospenda, Richman and Others 2005 J Bus Psychol

Rospenda KM, Richman J and Others "Is workplace harassment hazardous to your health?" 2005 J Bus Psychol 20(1) 95-110

Russo 2001 Education and the Law

Russo CJ "Recent Developments in the United States Supreme Court: Update on Sexual Harassment in Schools" 2001 Education and the Law 13(1) $69-75$

Snyman-Van Deventer and De Bruin 2002 Acta Academica Supplementum Snyman-Van Deventer E and De Bruin J "Sexual Harassment in South African and American Law" 2002 Acta Academica Supplementum 196-221

Thomas 2004 Brit J Soc Educ

Thomas AM "Politics Policies and Practice: Assessing the Impact of Sexual Harassment Policies in the UK Universities" 2004 Brit J Soc Educ 25(2) 143160 
Timmerman 2003 Sex Roles

Timmerman G "Sexual harassment of adolescents perpetrated by teachers and peers: an exploration of the dynamics of power, culture and gender in secondary schools" 2003 Sex Roles 48(5/6) 231-244

Venter, Chikanga and Hansen Citizen

Venter L, Chikanga K and Hansen D 'Sex abuse at South African Schools increases' The Citizen 26 October 20013

Walsh, Duffy and Gallagher-Duffy 2007 Can J Behav Sci

Walsh M, Duffy $J$ and Gallagher-Duffy $J$ "A More Accurate Approach to Measuring the Prevalence of Sexual Harassment among High School Students" 2007 Can J Behav Sci 39(2) 110-118

Wear, Aultman and Borges 2007 Teaching and Learning in Medicine

Wear D, Aultman JM and Borges NJ "Retheorizing Sexual Harassment in Medical Education: Women Student's Perceptions at Five US Medical Schools" 2007 Teaching and Learning in Medicine 20-29

\section{Register of case law}

Cram v Lamson and Session Co 49 F 3d 466 (8th Cir 1995)

Davis v Monroe County Board of Education 74 F 3d $1186\left(11^{\text {th }}\right.$ Cir 1996)

Davis v Monroe County Board of Education 526 US 629 (1999)

Doe v Town of Bourne 2004 WL 1212075 (D Mass)

Ellerth v Burlington Industries 912 F Supp 1101 (ND III 1996)

Farmer v Brennan 511 US 825 (1994)

Franklin v Gwinnett County Public Schools 503 US 60 (1992)

Gebser v Lago Independent Schools District 524 US 274 (1998)

Grobler v Naspers BPK 20045 BLLR 455 (C)

Henson v City of Dundee 682 F 2d 897 (11 ${ }^{\text {th }}$ Cir 1982)

J v M Ltd 198910 ILJ 755 (IC)

Kampmier v Emeritus Corp 472 F 3d 930 ( $7^{\text {th }}$ Cir 2007) 
Maepe v CCMA 2008 JOL 21837 (LAC)

Mokoena v Garden Court Art (Pty) Ltd 200829 ILJ 1196 (LC)

Ntshabo v Real Security CC 200324 ILJ 2341 (LC)

Prinsloo v Van der Linde 19976 BCLR 759 (CC)

PSA on behalf of Mthembu v Department of Health 2008 JOL 21638 (?)

Shrout v Black Clawson Co 689 F Supp 774 (SD Ohio 1988)

Soper $v$ Hoben 195 F 3d 845 ( $6^{\text {th }}$ Cir 1999)

Stadsraad van Pretoria v Pretoria Pools 19901 SA 1005 (T)

Stephen Vance $v$ Spencer County Public School District 231 F 3d 253 (6 ${ }^{\text {th }}$ Cir 2000)

Williams v Saxbe 413 F Supp 654 (DCDC 1976)

\section{Register of legislation}

Children's Act 38 of 2005

Compensation for Occupational Injuries and Diseases Act 130 of 1993 (as amended) Constitution of the Republic of South Africa, 1996

Criminal Law (Sexual Offences and Related Matters) Amendment Act 32 of 2007

Employment Equity Act 66 of 1995

Employment of Educators Act 76 of 1998 (as amended by the Education Amendment Act 53 of 2000)

Labour Relations Act 66 of 1995

Occupational Health and Safety Act 85 of 1993

Prevention of Family Violence Act 133 of 1993

Promotion of Equality and Prevention of Unfair Discrimination Act 4 of 2000

Protected Disclosures Act 26 of 2000

Sex Discrimination Act 1986 (Chapter 59 United Kingdom)

South African Council for Educators Act 31 of 2000

South African Schools Act 84 of 1996

\section{Register of government publications}

N 1367 in GG 19049 of 17 July 1998 (Code of Good Practice on the Handling of Sexual Harassment Cases) 
GN 1589 in GG 24165 of 3 December 2002 (Regulations to Prohibit Initiation Practises in Schools)

Gen N 1357 in GG 27865 of 4 August 2005 (Code of Good Practice on the Handling of Sexual Harassment)

\section{Register of internet sources}

Hill and Silva 2005 www.aauw.org

Hill C and Silva E 2005 Drawing the Line: Sexual Harassment on Campus www.aauw.org/learn/research/upload/DTLFinal.pdf [date of use 8 Jul 2011]

Human Rights Watch 2008 www.hrw.org

Human Rights Watch 2008 Universal Periodic Review of South Africa www.hrw.org/legacy/englishwr2k8/docs/2008/01/31/safric17797.htm [date of use 15 Sep 2008]

McGrath 2007 www.mcgrathinc.com

McGrath MJ 2007 The psychodynamics of school sexual abuse investigations www.mcgrathinc.com/ArticlePDF/PsychodynamicsSAlnvest.pdf [date of use 8 Jul 2011]

US EEOC [date unknown] eeoc.gov

US Equal Employment Opportunity Commission [date unknown] EEOC statistics eeoc.gov/eeoc/statistics/enforcements/sexual_harassment.cfm [date of use $13 \mathrm{Jul} 2011]$

\section{List of abbreviations}

$\begin{array}{ll}\text { Brit J Soc Educ } & \text { British Journal of Sociology of Education } \\ \text { BYU Educ \& LJ } & \text { Brigham Young University Education and Law Journal } \\ \text { Can J Behav Sci } & \text { Canadian Journal of Behavioural Science } \\ \text { Harv Rev Psychiatry } & \text { Harvard Review of Psychiatry } \\ \text { J Appl Psychol } & \text { Journal of Applied Psychology }\end{array}$


J Bus Psychol Journal of Business and Psychology

NW U L Rev

North-Western University Law Review

PWQ

Psychology of Women Quarterly

SAJE

South African Journal of Education

TFCLCR

Texas Forum on Civil Liberties and Civil Rights

TG Supp

Tydskrif vir Geesteswetenskappe Supplement 